\title{
Psikolojik Sermayenin Duygusal Emek Üzerine Etkisi: Hizmet Sektöründe Bir Araştırma

\author{
(Impact of Psychological Capital on Emotional Labor: A Research on Service Sector)
}

\author{
Duygu ÖZYILMAZ MISICAN (iDa Nuray TÜRKOĞLU iDb \\ a Meslek Yüksekokulu, Sinop Üniversitesi, Sinop, Türkiye. duyguozyilmaz@hotmail.com \\ a Gerze Meslek Yüksekokulu, Sinop Üniversitesi, Sinop, Türkiye. nurayturkoglu@yahoo.com.tr
}

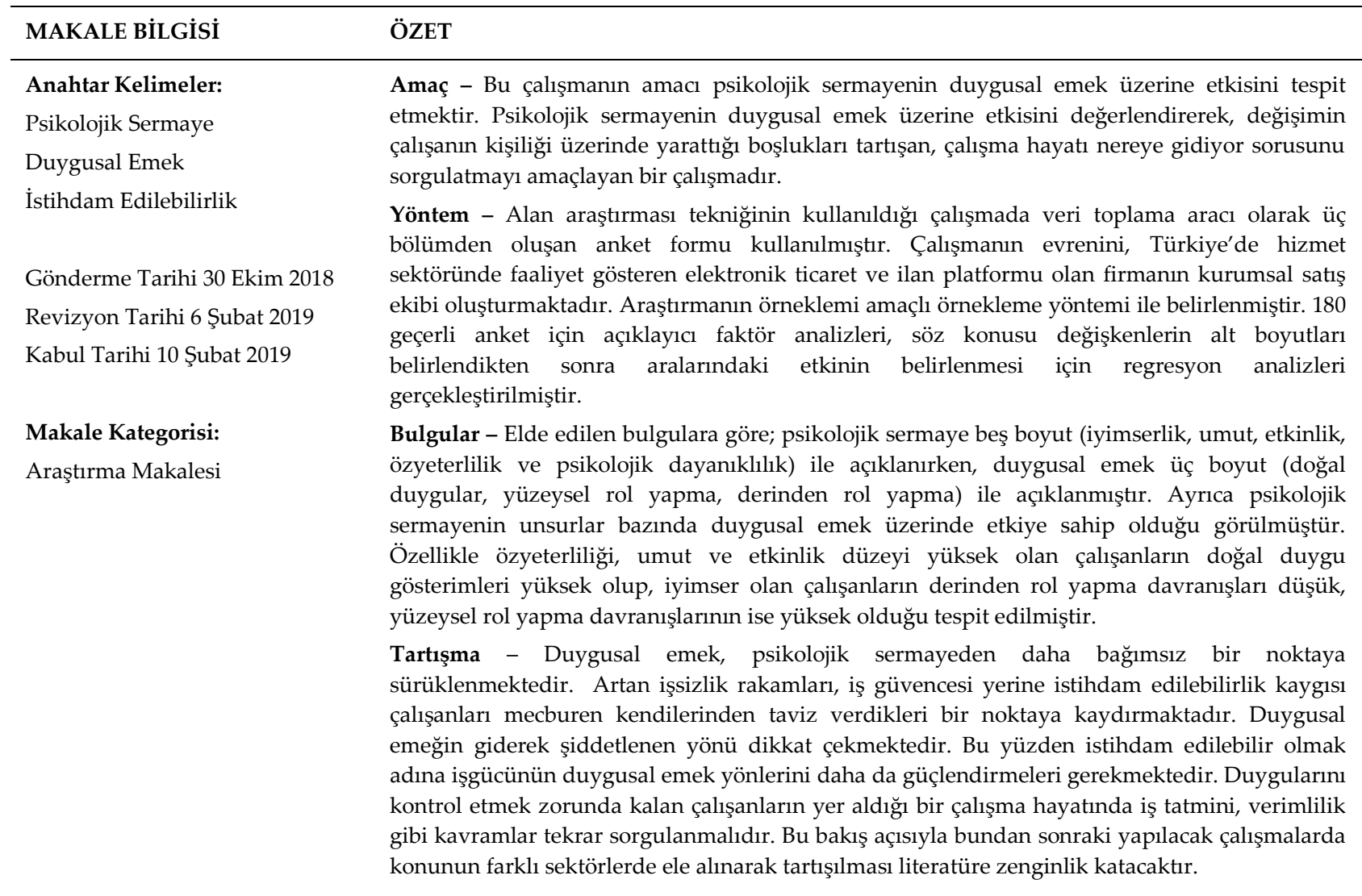

\begin{tabular}{ll}
\hline ARTICLE INFO & ABSTRACT \\
\hline $\begin{array}{l}\text { Keywords: } \\
\text { Psychological Capital }\end{array}$ & $\begin{array}{l}\text { Purpose - The purpose of this study is to determine the impact of psychological capital on } \\
\text { emotional labor. This is a study aimed at questioning the question of where the working life is } \\
\text { Emotional Labor }\end{array}$ \\
$\begin{array}{l}\text { going, discussing the gaps created by the change of the employee on the personality by } \\
\text { evaluating the psychological capital's influence on emotional labor. } \\
\text { Design/methodology/approach - In the study in which the field research technique was } \\
\text { applied, a questionnaire consisting of three parts was used. In the first part, there are questions } \\
\text { to determine the demographic characteristics of the employees, while there are scales to } \\
\text { determine psychological capital and emotional labor orientation in the second and third part. } \\
\text { The universe of the study consists of company's corporate sales team, which has the feature of a } \\
\text { firm operating as the platform of electronic trade and advertisement in Turkish service sector. } \\
\text { Revised 6 February 2019 }\end{array} \quad \begin{array}{l}\text { The sample of research was determined by the sampling method of the research. } 80 \text { valid } \\
\text { surveys have been acquired. Explanatory factor analyzes for the scales and regression analyzes } \\
\text { Accepted 10 February 2019 }\end{array}$ \\
$\begin{array}{l}\text { were performed to determine the interaction between the variables after the sub-dimensions of } \\
\text { the variables were determined. }\end{array}$ \\
Research Article & $\begin{array}{l}\text { Findings - According to findings acquired, emotional labor was explained with three } \\
\text { dimensions (natural emotions, superficial role, deep role play), while psychological capital was }\end{array}$ \\
\hline
\end{tabular}


explained with five dimensions (optimism, hope, efficacy, self-efficacy and psychological endurance). It has also been found that the psychological capital has some influence on emotional labor. In particular, employees with high self-efficacy, high hopes and efficiency levels showed high levels of natural emotions, and on the other hand, the optimistic employees had low role-playing behaviors and superficial role-playing behaviors.

Discussion - The concept is moving from a psychological capital to a more independent point. Increasing unemployment figures and the anxiety about employability instead of demand of job security compulsorily carry the workers to a point where they make concessions about themselves. It was also remarkably important that the emotional labor is becoming more and more intense. Therefore, in order to be employable, it is necessary to strengthen the aspects of the workforce related with the emotional labor. Concepts such as job satisfaction and productivity should be questioned again in a working life where employees have to control their emotions. From this point of view, it will enrich the literature by discussing the subject in different sectors.

\section{Giriş}

Çalışma hayatının fetişist kimliği her geçen gün daha da şiddetini artırmaktadır. Son yıllarda yapılan çalışmalardaki (Kart, 2010; Misican ve Bedir, 2017; Froymovich, 2013) ortak sonuç, çalışanın kişiliklerinden tavizler vererek istihdam edilebilirliklerini korudukları yönündedir.

Artan işsizlik rakamları, esnekleşme, çalışma hayatında kuralsızlaştırma, yeni teknolojiler, iş güvencesi yerine istihdam edilebilirlik kavramına geçiş çalışan tavizlerinin nedenlerindendir. Çalışanlar istihdamlarını koruyabilmek adına fiziksel, sosyal ve psişik bütün özel alanlarını çalışma hayatındaki değişime adapte etmek zorunda bırakılmaktadır (Gorz, 2001: 58-118). Bu değişimin bütün yükü çalışanın omuzlarına yüklenmektedir. Kendini bu değişime adapte edebilen çalışanlar çalışma hayatının çeperine otururken; bu değişimin dışında kalanlar çalışma hayatının da dışında kaymaktadır.

İşlerini kendisi olarak görme olarak ifade edilmeye başlayan biyoproleterya çalışanlar (Rifkin, 1995: 67) kendi çalışma sürelerini uzatarak mesai saatleri kavramını zamanın çok daha ötesine taşımaktadır. Çalışanın kişiliğini pazarlanabilir bir vasıf olarak ortaya çıkaran değişim, çalışma hayatının geldiği noktayı sorgulatmaktadır. Sennett (2012) bu değişimi "karakter aşınması" olarak değerlendirmekte ve çalışanların kişiliklerinde bir sürüklenme yaşadıklarını ifade etmektedir.

Çalışma hayatının geldiği noktada çalışanın kişiliği iş güvencesi sağlayan bir vurgu olarak göze çarpmaktadır. Bu yüzden çalışma hayatında yaşanan değişimin ortaya çıkardığı duygusal emek ve psikolojik sermaye kavramı daha da ön plana çıkmaktadır. Psikolojik sermaye kavramı çalışanların pozitif yönlerine odaklanarak en iyi olabilme yönüne vurgu yapmaktadır. Bu vurgu bu yönü güçlü olan çalışanlara rekabet avantajı tanımaktadır. Çalışanın kendi duygularını ve kişiliğini gizleyerek iş süreçlerinde profesyonel duygu sergilemelerini ifade eden duygusal emek kavramı ise, çalışanın kişiliğinde firmanın kâr ve verimlilik duygusunu daha da hissettirmektedir.

$\mathrm{Bu}$ çalışma psikolojik sermayenin duygusal emek üzerine etkisini değerlendirerek, değişimin çalışanın kişiliği üzerinde yarattığı boşlukları tartışan, çalışma hayatı nereye gidiyor sorusunu sorgulatmayı amaçlayan bir çalışmadır. Literatürde psikolojik sermayenin duygusal emek üzerinde etkilerini ele alan çok sayıda çalışma mevcuttur. Bu çalışmalardaki genel sonuçlar (Begenirbaş, 2015; Kara ve Begenirbaş, 2016; Çetin vd., 2013), psikolojik sermayenin duygusal emek üzerinde doğal duyguları pozitif yönde etkilediği, derinden rol yapma ve yüzeysel rol yapma davranışını negatif yönde etkilediği net ifadelerden oluşmaktadır. Ancak bu çalışma literatürden farklı olarak duygusal emeğin artan yönüne vurgu yapmak istemektedir. Duygusal emeğin psikolojik sermayeden daha bağımsız bir şekilde büyüyerek psikolojik sermayesi daha düşük olan çalışanların bile duygusal emek davranışına yönlendiğinin altını çizmektedir. Psikolojik sermayesi güçlü olan çalışanların doğal duygu davranışı sergileyebilmelerinin yanında yüzeysel rol yapma tavrıda gösterebildiklerini ifade etmektedir. Vurgulanmak istenen nokta, çalışanların istihdam edilebilirliklerini koruyabilmek adına kişikliklerine uygun olmayan durumlarda bile profesyonel bir çalışma tavrı sergilemek zorunda bırakılmalarıdır. Bu yüzden duygusal emek çalışanların sahip olmaları gereken ve bu yönlerini geliştirmek zorunda bırakıldıkları bir boyuta ulaşmaktadır. Çalışma hayatının istediği profesyonel iş davranışını sergileyebilmek adına çalışanlar kişiliklerine ve hissettikleri duygularına aykırı bile olsa duygusal emeğin alt boyutu olan doğal duygu davranışına girmek zorunda kalmaktadırlar. Artan 
işsizlik ve işgücü arasındaki rekabet bu sonucu doğurmaktadır. Artık günümüz çalışma hayatında yaşanılan değişim sürecinin işgücünün kişiliği üzerinde yarattığ1 kayıplar, işgücü tarafından da normal karşılanmaktadır. Başka bir ifadeyle günümüzde neyin normal neyin anormal olduğu belirginliğini yitirmektedir. Öyle ki, standart bir normalden ziyade yaşanılan sürecin belirlediği bir normaller dizisi bulunmaktadır (Geçtan, 2003: 10-11). Çalışma hayatının normalleştirdiği sahte duygu takınma tavrı da artık çalışma hayatının beklediği profesyonel kimlik yapısını oluşturmaktadır.

$\mathrm{Bu}$ aktarımlar ışığında çalışmada duygusal emeğin derinden rol yapma davranışı yönünün daha ön planda olması beklenmektedir. Çünkü duygusal emek kavramının giderek artan etkisi çalışanlar üzerinde kıdem, yaş, pozisyon, kuşak ayrımı olmaksızın çalışanları istihdam edilebilir olmak adına duygusal emek yönü güçlü bir çalışan kişiliğinde buluşturmaktadır. Bu doğrultuda çalışmada psikolojik sermaye ve duygusal emeğin kavramsal çerçevesi ifade edildikten sonra yöntem kısmında çalışmanın amaç, hipotez, veri toplama aracı, araştırmanın evren ve örneklemine değinilecektir. Araştırmanın bulguları kısmında analizlerle detaylandırılacaktır. Sonuç kısmında ise elde edilen bulgulardan yola çıkılarak çalışma hayatı ile ilgili çıkarımlarda bulunulacaktır.

\section{Kavramsal Çerçeve}

\subsection{Psikolojik Sermaye}

Pozitif psikoloji temelinde Luthans ve Youssef tarafından ilk kez kullanılan ve Seligman tarafından geliştirilen kavram çalışanların pozitif yönlerine odaklanarak daha iyi olma ve bunu örgütler için rekabet avantajı durumuna çevirebilme özelliğine dayanmaktadır (Luthans vd., 2010:41; Brandt vd., 2011: 269). Bu pozitif psikolojik durum, süreklilik gösteren bir karakteristik özelliği vurgulamamakta, durumlara ve olaylara göre değişebilen, farklılaşabilen bir niteliği barındırmaktadır (Çetin ve Basım, 2012: 123). Kişiliğin deneyim, yaş, eğitim ve çevresel faktörlerle değişebilen ve geliştirilebilen özelliğine vurgu yapan çalışmalarda, psikolojik sermayenin kişisel ve örgütsel performansın geliştirilmesi ve yönlendirilmesine oldukça olumlu katkılar yaptığı belirlenmiştir (Luthans ve Youssef, 2007). Kavram, çalışanların duygularının ve ruh hallerinin iş performanslarını ve iş tatminlerini nasıl etkilediğini de ifade etmektedir (Weiss ve Cropanzano,1996: 65). Bu bağlamda, psikolojik sermaye kişisel seviyede, gelişim ve performansı teşvik edebilen bir kaynak olarak görülmektedir.

Psikolojik sermaye kavramı dört temel unsurdan oluşmaktadır. Bu unsurlar; umut (hope), iyimserlik (optimism), öz-yeterlilik (self-efficacy) ve dayanıklılıktır (resilience) (Duffy, 2013: 98). Umut, arzu edilen amaçlara ulaşmada algılanan yol ve yöntemler üretme, hedef yönelimine göre yollar planlayarak bu yolları kullanma konusunda kendi kendini motive etme yeteneği olarak tanımlanmaktadır (Peterson vd., 2011: 430). Umudun üç bileşeni vardır. Bunlar; irade, yollar ve hedeftir. Çalışanın değerli amaçlar belirleyebilme ve bu amaçları elde etmede engellerin üstesinden gelebilme gücünü içeren motivasyonel bir durumdur. Bu unsurun merkezinde, çalışanın hedefleri için seçtiği metotlar, yollar ve bu yollardan bir diğerine geçebilme becerisi ve motivasyonu vardır. Yapılan çalışmalarda umutlu kişilerin daha fazla motive olup, zorluklarla karşılaştıklarında alternatif yollara saptıkları ve yüksek performansla hedeflerine ulaştıkları saptanmıştır (Luthans ve Jensen, 2002).

İyimserlik, gelecek olaylar hakkında pozitif beklenti ve düşüncelere sahip olma ve bu olaylara pozitif nitelikleri atfetme ile ilgilidir (Harms ve Luthans, 2012: 590). İyimser kişilerin gelişen bir duruma karş1 bakışları farklıdır. İyimser kişiler, pozitif olayları içselleştirme ve negatif olayları dışlama eğilimi göstermektedir (Seligman; 1998). Kötü olayları dişsal faktörlerle ilişkilendirip kendi hataları olmadığını düşünmektedirler. Ayrıca yaşanılan durumu değişken ve spesifik bir olay olarak görürler (Seligman, 1998). $\mathrm{Bu}$ düşünce tarzları engelleri başarısız olarak görmeyip onları farklı yollara iterek başarılı olma ve performans arttırıcı bir durum olarak motivasyon sağlamaktadır (Luthans vd., 2004: 47).

Seligman (2006: 256-258) iyimserliğin firmaya katkısını üç yönden ele almaktadır. İlki, iyimser olan çalışanların baskı altında daha üretken bir tavır sergiledikleridir. İşe aidiyetleri yüksek olan çalışanların firmalarda personel devir hızı ve eğitim maliyetleri düşük olacağından firmanın iş tatmini, üretkenliği ve performansı artacaktır. İkincisi, iyimser çalışanların kişilik özellikleri dikkate alınarak daha stresli operasyonlarda kullanılması gerektiğidir. Üçüncüsü ise, firmanın iyimserliğin artırılabilmesi için iyimserlik düzeyinin yükseltilmesi için çaba sarf edilmesidir. 
Özyeterlilik, çalışanın kendi içsel motivasyonu ile harekete geçerek belirlediği hedefe yönlenebilme gücüdür. Kilit noktası kendine duyulan özgüvendir (Bandura, 1982: 122).Çalışanın içsel motivasyonuyla farklı yollar ve metodlar deneyerek başarılı olmaya güdülenmesi olarak ta tanımlanmaktadır (Avey vd., 2008: 53). Çalışanın iş performansı üzerinde etkisinin kanıtlanmış olması nedeniyle pozitif örgütsel davranış özelliklerini en iyi karşılayan kavramdır (Luthans vd., 2010). Özyeterliliğin beş özelliği vardır (Luthans vd., 2007). İlki kendine özgü olma özelliğidir. Çalışanın bir alanda kurduğu öz yeterlilik her alanda kendini göstermeyebilir. Diğer özelliği uygulamaya dayanmasıdır. Deneyim kazandıkça öz yeterliliği olduğu alanı daha da geliştirebilir, öz yeterliliği olmadığı konularda ise hiç deneyime sahip değildir. Üçüncü özellik, gelişime açık olmasıdır. Bu özellik çalışana kendini yeterli gördüğü alanlarda bile sürekli öğrenmeye ve gelişime açı olmasını ifade eder. Diğer özelliği başkalarından pozitif etkilenmeleridir. Diğer insanların başarılı olduğu noktaları gözlemleyerek, kendisinin de benzer alanlarda başarılı olabileceğine dair bir düşünce geliştirirler. Son özelliği değişken olmasıdır. Çevresel faktörlere ve çalışana bağlı olarak değişebilmektedir.

Dayanıklılık, risk veya zorluklarla karşılaşıldığında, bu engellere karşı pozitif tepki gösterme ve uyum sağlama özelliğidir (Norman vd, 2010: 381). Sıkıntı, başarısızlık, belirsizlik, baskı gibi ortamlarda kalan çalışanın pozitif düşünerek sıçramaya harekete geçme durumunu ifade etmektedir (Avey vd.,2008: 4). Kavram sadece olumsuz durumlarla değil, olumlu olaylar karşısında da çalışanın baş etme yeteneği olarak ifade edilmektedir. Sorumluluğu artan yâda terfi eden bir çalışanın yeni durumuna anında adapte olarak mücadeleye başlama iradesi olarak ta tanımlanmaktadır (Luthans vd., 2007). Dayanıklılık, yaşanılan olayları olumlu değerlendirmesi sonucunda çalışanın kişisel çabaya ve azme dayalı harekete geçirilmiş bir başarıyı göstermektedir (Luthans ve Youssef, 2007). Dayanıklılığı diğer psikolojik sermayenin özelliklerinden ayıran yanı olumsuzluklar karşısında hem reaktif hem de proaktif davranışlar gerektirmesidir. Reaktif olarak dayanıklılık, yaşanılan olumsuz ya da olumlu durumlarda bile yaşanılan sürecin en iyimser insanlarda bile yıkıcı etkisi olduğunu, bunun geçici bir süreç olduğunu kabul ederek kendilerini toplama ihtiyacını doğurduğunu kabul etmektedir. Proaktif dayanıklılık ta ise, yaşanılan olumsuzlukların fırsata çevrilerek olayı sıçrama tahtası olarak görmesi anlamına gelmektedir (Luthans ve Youssef, 2007).

Psikolojik sermayenin tüm faktörleri birbirleri ile ilişkili bir yapıdadır. Umutlu çalışanlar, zorlukların ve başarısızlıkların üstesinden gelmek konusunda daha inançlıdırlar ve bu yüzden psikolojik dayanıklılıkları daha fazladır. Öz-yeterlilikleri yüksek çalışanlar ise umut, iyimserlik ve dayanıklılık yönlerini yaşanılan olumsuz durumlarda kolayca adapte ederek engellerin üstesinden gelebilirler (Luthans vd., 2007: 19).

$\mathrm{Bu}$ aktarımlar ışığında psikolojik sermaye; çalışanın pozitif psikolojik durumunu içermektedir (Avey vd., 2008: 54). Bu pozitif psikolojik durum çalışanın içsel motivasyonunu yükselterek yaptığı işte herzaman başarılı olabileceğini, her işin üstesinden gelebileceğini, belirlediği her hedefe ulaşabileceğini güdülemektedir. Psikolojik sermaye, birçok pozitif örgütsel davranış kriterini bir araya getiren ve bütünleştiren bir yapıdır.

\subsection{Duygusal Emek}

Weber'in iş yerinde başarıya ulaşabilmek için duyguların bastırılması, gizlenmesi yönünde yaklaşımı içeren bürokrasi kuramıla beraber yapılan çalışmalarda duyguların yönetilebildiği sürece firmaya olumlu katkı sağlayacağı düşüncesinin yaygınlaşması, duygu yönetimini firma için önemli bir meta haline getirmektedir. Türk Dil Kurumu sözlüğünde "belirli nesne, olay veya bireylerin insanın iç dünyasında uyandırdığı izlenim" olarak tanımlanan duygunun yalnızca içsel dünyamızı ilgilendirmediği, aynı zamanda çevre ile uyumu sağlayıcı ya da bu uyumu bozucu, kişiyi harekete geçiren veya durağanlaştıran yönleri de olduğu ifade edilmiştir (Hebb,1958: 109-113). Bu bağlamda çalışma hayatındaki değişim çalışan duygularını da etkilemeye başlamaktadır.

Çalışma hayatı sadece çalışanların davranışlarını değil hislerini de kontrol etmeye yöneldikleri bir yapıya dönüşmektedir. İlk kez Hochschild (1983) tarafından kullanılan kavram, bir ücret için duyguların yönetilmesi olarak ifade edilmiştir (Grandey, 2000: 95). Duygusal emek, işletmelerin istediği davranış kurallarını sergileyebilmeleri için kişilerin duygularını düzenleme, yönetme süreci şeklinde tanımlanmaktadır (Diefendorff ve Gosserand, 2003). Çalışanların iş süreçlerinde müşterilerle ve firması ile empati kurması, belirlenmiş rol kalıplarını benimsemesi ve hissetmeseler bile duygularını firmalarının politikasıyla eş değer bir kalıba dönüştürmeyi içermektedir (Onay, 2011: 587). Duyguların başarılı bir 


\section{D. Özyılmaz Misican - N. Türkoğlu 11/1 (2019) 173-188}

şekilde yönetilmesi (Tuna, 2008: 18), duygusal ifadenin değiştirilmesi için duyguların bastırılması, değiştirilmesi veya abartılmasını olarak adlandıılan kavramda (Grandey, 2000) ortak vurgu çalışanın gerçek duygularının gizlenmesidir.

Duygusal emek, çalışanın hissettiği duyguları bastırarak, yaptığı işin gereksinimlerine uygun duygu kalıbı içine kendini sokabilmesidir. Duygularını firma politikalarıyla uyumlu hale getirmesi istenen çalışandan yapay duygu sergilemesi beklenmektedir (Mann, 2007). Çalışanlar, sahte bir tavır sergileyerek gerçek hislerine ve gerçek kendilerine yabancılaşmaktadır (Lupton, 2002: 39). Çalışanlar kendi kimliklerini askıya almakta (Kart, 2010: 325), işverenler tarafından verilen yeni kimliklerine bürünmek zorunda bırakılmaktadır. Kart'a göre (2010: 350); çalışanlar bu duygu yönetimlerini müşterilerinin yanında değil bütün sosyal alanlarda taşımak zorunda kalmakta, kurum kimliği ve kültürüne uygun giyim, davranış ve iletişim biçimlerine de ayrıca özen göstermek zorundadırlar. Kart bu durumu yaptığı araştırmalarda görüşmecilerin, daha lüks yerlerde yemek zorunda olduklarını, daha iyi giyinmek zorunda olduklarını, sürekli imajlarına dikkat ettiklerini, morallerini yüksek tutmak için anti depresan kullandıklarını, tebessümlerin gerçek olmasa bile tebessüm etmek zorunda kaldıkları şekilde aktarmaktadır. (Kart, 2010: $256,282,314,346)$.

Literatürde duygusal emeği olumlu ve olumsuz boyutlarıyla ele alan çalışmalar mevcuttur. Genellikle olumsuz boyutlarıyla ele alan çalışmalarda kavram yabancılaşma, tükenmişlik, stres ve iş tatmininin azalması sonuçlarıyla ele alınmaktadır (Lam ve Chen, 2012; Judge vd, 2009; Pugliesi, 1999; Yang ve Chang, 2008). Olumlu bakış açısına sahip çalışmalarda, duygusal emek kavramı empati kavramı ile ilişkilendirilerek iletişim içinde olunan kişilerle empati yapılarak kendi duygularını dikkate almadan karşıdakinin duygularını anlamaya çalışıldığı şeklinde ifade edilmektedir (Kleinman ve Coop, 1993; Man ve Öz, 2009, 7980).

Duygusal emeğin yüzeysel rol yapma, derinden rol yapma ve doğal duygulardan (samimi davranış) oluşan üç boyutu vardır (Hochschild, 1983; Asforth ve Humphrey, 1993). Yüzeysel rol yapma çalışanın gerçekte hissettiği duygulardan farklı duygular sergilemesidir. Çalışanların firma tarafından istenen duyguları dış görünüşlerinde değişiklikler yaparak (yüz ifadesi, jest ve ses tonu gibi) hissediyormuş gibi görünmesi olarak tanımlanmaktadır (Chu ve Murrmann, 2006, 1182). Çalışanlar kendi duygularını kamufle ederek duygularını kontrol altına almaktadırlar (Brotheridge ve Grandey, 2002: 22). Çalışanların gerçek duygularını değil sadece davranışlarını değiştirmeleri söz konusudur (Asforth ve Humprey, 1993: 92). Çalışan olumsuz duygularını gizleyerek olumlu davranış kalıbı sergilemektedir (Diefendorff vd., 2005, 340). Derinlemesine rol yapma boyutu çalışanın sadece dış görünüşünde değil aynı zamanda duygularını da değiştirdiği durumu ifade etmektedir (Chu ve Murrmann, 2006, 1182). Bu boyut, çalışanların içsel duygularına odaklanmakta firmanın sergilenmesini istediği duyguları gerçekten yaşamayı ve hissetmeyi denemesini içermektedir (Ashforth ve Humprey, 1993: 93). Bu durumda çalışan sadece dış görüntüsünde değişikliğe gitmemekte, sergilemesi gereken duyguları kendi içinde de hissedebilmek için çaba harcamaktadır (Diefendorff vd., 2005: 340). Ashforth ve Humprey (1993: 94) bu iki boyuta, çalışanların yüzeysel ve derinden rol yapmalarına gerek kalmadan, gerçek duygu durumlarıyla hizmet edebileceklerini belirten doğal duygular boyutunu da eklemişlerdir. Ashforth ve Humprey (1993) bazı durumlarda çalışanların duygularını doğal ve içten bir şekilde sergilediğini öne sürmüşlerdir. Duyguların doğal yolla ifadesi, dışadönüklük ve geçimlilik özellikleriyle açıklanarak, bireylerin olumlu duygular içinde olması ve olumlu ilişkiler aramaları dolayısıyla, rol yapmadan bu şekilde davranabildiklerini ifade etmektedir (Diefendorff vd., 2005: 352).

Yapılan çalı̧̧malarda, yüzeysel rol yapma boyutunun olumsuz, derinlemesine rol yapma boyutunun olumlu çıktılarla ilişkilendirildiği görülmektedir. Çalışanın yüzeysel rol yapma davranışında duygusal tükenme (Brotheridge ve Lee, 2003) ve tükenmişlik (Grandey, 2000) sendromları görülmektedir. Özellikle yüzeysel rol yapma davranışında duygusal çelişki ortaya çıkmaktadır. Derinlemesine rol yapma davranışında ise kişisel başarma (Brotheridge ve Grandey, 2002), performans artışı (Grandey, 2000), işten ayrılma niyetinin azalması (Chau vd., 2009) ve işe bağlılığın artması gibi olumlu sonuçlar tespit edilmektedir (Çelik ve Öz, 2011; Scott ve Barnes, 2011). İş tatminini arttıran ve tükenmişliği azaltan davranış biçimi genellikle derinden rol yapma davranışı iken; tükenmişliğin ortaya çıkması ve iş tatminin azalmasının sebebi ise yüzeysel rol yapma davranışıdır (Lam ve Chen, 2012). 


\section{Metodoloji}

\subsection{Araştırmanın Amacı ve Hipotezleri}

Günümüz çalışma hayatında istihdam edilebilirlik ön plana çıkmaktadır. Çalışanlar kendilerini bu değişime adapte ederek istihdam edilebilir olmak adına kişiliklerini ve hatta duygularını da dönüştürmek zorunda bırakılmaktadır. Yapılan alan çalışmalarında da bu dönüşüm görülmektedir (Kart, 2010; Misican ve Bedir, 2017; Froymovich, 2013; Bora,vd., 2012). Özellikle bu dönüşüm süreci hizmet sektöründe, hizmet alanlarla yüz yüze kurulan ilişkilerde duygu gösterimleri daha ön planda olduğundan daha iyi gözlemlenmektedir. Çalışanların hissetmediği duyguları firmanın kâr ve verimlilik istekleri doğrultusunda hissediyormuş gibi göstermek zorunda bırakılması çalışanlarda olumsuz psikolojik etkiler yaratabilmektedir (Kaya ve Özhan, 2012). Bu yüzden psikolojik sermayesi güçlü olan çalışanların duygu gösterimlerini kontrol edebilmeleri daha da kolaylaşabilmektedir. Pozitif duygular kuramı (Fredrickson, 2001) da pozitif psikolojik sermaye kavramı ile duygusal emek gösterimlerini ilişkilendirmektedir. Özgüvenli, zorluklarla karşılaşıldığında pes etmeden mücadele edebilen psikolojik dayanıklılığı yüksek, umutlu ve iyimser olan çalışanların çalışma ortamlarına gerçek duygularını yansıtarak, kişilikleri ve yaptıkları iş kimlikleri arasında kopma olmadan daha bilişsel ve duygusal fonksiyon seviyelerinde çalıştıkları ortaya çıkarılmıştır (Fredrickson ve Losada, 2005). Bu çerçevede Luthans vd.,2002; Luthans ve Youssef, 2007; Luthans vd., 2007; Seligman, 2002; Çelik vd., 2011; Begenirbaş, 2015 çalışmalarından yola çıkarak psikolojik sermaye ve duygusal emek alt boyutları arasında aşağıdaki hipotezler geliştirilmiştir.

Hipotez 1: Çalışanların iyimserlik duyguları doğal duygularını pozitif yönde etkilemektedir.

Hipotez 2: Çalışanların umut düzeyleri doğal duygularını pozitif yönde etkilemektedir.

Hipotez 3: Çalışanların etkinlik düzeyleri doğal duygularını pozitif yönde etkilemektedir.

Hipotez 4: Çalışanların öz yeterliliği doğal duygularını pozitif yönde etkilemektedir.

Hipotez 5: Çalışanların psikolojik dayanıklılık düzeyi doğal duygularını pozitif yönde etkilemektedir.

Hipotez 6: Çalışanların iyimserlik duyguları yüzeysel rol yapma duygularını pozitif yönde etkilemektedir.

Hipotez 7: Çalışanların umut düzeyleri yüzeysel rol yapma duygularını pozitif yönde etkilemektedir.

Hipotez 8: Çalışanların etkinlik düzeyleri yüzeysel rol yapma duygularını pozitif yönde etkilemektedir.

Hipotez 9: Çalışanların öz yeterliliği yüzeysel rol yapma duygularını pozitif yönde etkilemektedir.

Hipotez 10: Çalışanların psikolojik dayanıklılık düzeyi yüzeysel rol yapma duygularını pozitif yönde etkilemektedir.

Hipotez 11: Çalışanların iyimserlik duyguları derinden rol yapma durumlarını pozitif yönde etkilemektedir.

Hipotez 12: Çalışanların umut düzeyleri derinden rol yapma durumlarını pozitif yönde etkilemektedir.

Hipotez 13: Çalışanların etkinlik düzeyleri derinden rol yapma durumlarını pozitif yönde etkilemektedir.

Hipotez 14: Çalışanların öz yeterliliği derinden rol yapma durumlarını pozitif yönde etkilemektedir.

Hipotez 15: Çalışanların psikolojik dayanıklılık düzeyi derinden rol yapma durumlarını pozitif yönde etkilemektedir.

Çalışmada kurulan hipotezlerin cevaplarından yola çıkarak çalışma hayatının geldiği nokta tartışılmak istenmektedir. Psikolojik sermayenin duygusal emek üzerindeki etkisi göz önüne alınarak psikolojik sermayesi düşük olan çalışanların duygusal emek yönlerinin güçlü olup olmadığı araştırılmaktadır. Duygusal emek artık istihdam edilebilirliğin olmazsa olmaz parçasıdır. Çalışanların ister psikolojik sermayeleri yüksek olsun isterse düşük olsun duygu kontrollerini sağlamak zorunda bırakılmaktadırlar. Bu çalışma bu sorunun cevabına ışık tutmayı amaçlamaktadır.

\subsection{Evren ve Örneklem}

Çalışmanın evrenini, Türkiye'de hizmet sektöründe faaliyet gösteren elektronik ticaret ve ilan platformu olma özelliğini taşıyan firmanın kurumsal satış ekibi oluşturmaktadır. Sektörün dinamik yapısı, istihdamının da sürekli yenilikçi ve yüksek nitelikli yapısını gerekli kılmaktadır. İşe alım süreçlerinde eğitim 
ve kişiliğin değer taşları olarak görülmesi sektörde nitelikli işgücünü gerekli kılmaktadır. Kurumsal satış personelinin ele alınmasındaki amaç ise; satış hedeflerine ulaşılmasında kişiliğin performans kriteri olarak görülmesidir. Satış hedefleri için birebir müşterilere yüz yüze geldikleri için duygu kontrolleri bu ekip için ön plandadır. Bu durumda çalışma evreninin, çalışmanın amacı doğrultusunda sağlıklı sonuçlar alınabilmesi için uygun olduğu düşünülmektedir. Ancak genel evrenin tamamına ulaşmak zaman sorunu ve maddi kısıtlardan dolayı zor olduğu için çalışmanın amacı doğrultusunda amaçlı (kasti) örnekleme yöntemi çerçevesinde evren indirgenmeye çalışılmıştır. Amaçlı (Kasti) örnekleme; örnekleme dâhil edilecek birimlerin araştırmacının bilgi, deneyim ve gözlemlerinden hareketle araştırmanın amacına uygun olarak kendi yargısıyla belirlediği yöntemdir (Ural ve Kılıç, 2013: 43). Bu çalışmanın örneklemini elektronik ticaret ve ilan platformunda yaygın kullanımıyla öne çıkan, ancak firmanın prosedürüne göre isminin kullanılmasını istemeyen alanındaki en büyük ve kurumsal olduğu bilinen $\mathrm{X}$ işletmesi oluşturmaktadır. 2018' de söz konusu firma çalışan kurumsal satış elemanı sayısı 320 kişidir. Buna bağlı örneklem büyüklüğü aşağıdaki şekilde hesaplanmıştır (Ural ve Kılıç, 2013: 45).

$\mathrm{N}=\mathrm{N} \cdot \mathrm{t}^{2} \cdot \mathrm{p} \cdot \mathrm{q}$

$\mathrm{d}^{2} \cdot(\mathrm{N}-1)+\mathrm{t}^{2} \cdot \mathrm{p} \cdot \mathrm{q}$

(N: Evrendeki birey sayısı; n: Örnekleme alınacak birey sayısı; p: İncelenecek olayın görülüş sıklı̆̆ı; q: İncelenecek olayın görülmeyiş sıklığı (1-p); t: Belirli serbestlik derecesinde ve saptanan yanılma düzeyinde $t$ tablosunda bulunan teorik değer; d: Olayın görülüş sıklığına göre yapılmak istenen +, - sapmadır. t: 1.96.)

Yukarıdaki formülden hareketle örneklem büyüklüğü 175 kişi olarak hesaplanmaktadır. Veriler 01.12.2017 15.06.2018 tarihleri arasında toplanmış ve geçerli 180 ankete ulaşılmıştır.

\subsection{Veri Toplama Aracı}

Veri toplama aracı olarak anket formu kullanılmıştır. Anket formu üç bölümden oluşmaktadır. İlk bölümde katılımcıların demografik özelliklerine ait bilgilere, ikinci bölümde Psikolojik Sermaye Ölçeğine, son bölümde ise Duygusal Emek Ölçeğine yer verilmiştir. Çalışmanın amacı doğrultusunda çalışanların demografik özelliklerini belirlemeye yönelik sorular araştırmacı tarafından uzman görüşlerine de başvurularak oluşturulmuştur.

Psikolojik Sermaye Ölçeği: Luthans vd.,2007 tarafından geliştirilen 24 maddelik bir ölçektir. Ölçek umut, iyimserlik, öz-yeterlilik ve psikolojik dayanıklılık olmak üzere 4 alt boyuttan oluşmaktadır. Kullanılan ölçek, Çetin ve Basım (2012) tarafından Türkçeye uyarlanmıştır. Ölçek, 5'li Likert tipi ifadelerden oluşmaktadır. (1=Hiç Katılmıyorum, 5= Tamamen Katılıyorum). Ölçeğin 1.-9.-11.-14.-18. ve 19. soruları iyimserlik boyutunu; 2.- 6.- 12.- 17.- 20. ve 24. sorular umut boyutunu; 3.- 4.- 12.- 15.- 16.- 21.- ve 23. sorular öz yeterlilik boyutunu; 5.- 7.- 8.- 10.- 13. ve 22. sorular ise psikolojik dayanıklılık boyutunu ölçmektedir.

Duygusal Emek Ölçeği, Diefendorff vd., (2005) tarafından, Grandey (2003) ve Kruml ve Geddes'ın (2000) duygusal emek ölçeklerinin bazı maddelerinin alınarak uyarlanması ve bazı maddelerin ise geliştirilmesiyle oluşturulan ölçektir. Kullanılan ölçek, Basım ve Begenirbaş (2012) tarafından Türkçeye uyarlanmıştır. Ölçek, yüzeysel rol yapma, derinden rol yapma ve doğal duygular olmak üzere üç boyutu içermekte ve 5’li Likert tipi ifadelerden oluşmaktadır. (1=Hiç Katılmıorum, 5= Tamamen Katılıyorum). İlk yedi soru yüzeysel rol yapma boyutunu, 8.9.10.ve 11. sorular derinden rol yapma boyutunu, 12.-13. ve 14. sorular ise doğal duygular boyutunu ölçmektedir.

\section{Araştırmanın Bulguları}

\subsection{Katıllmcıların Demografik Özellikleri}

Örneklem, 180 kişiyi kapsamaktadır. Ankete katılanların \%54,4'ü (98 kişi) erkek, \%45,6'sı (82 kişi) kadın; \%56,7'si (102 kişi) bekâr, \%26,7'si (48 kişi) evli ve \%16,7'si (30 kişi) eşinden ayrılmıştır. Katılımcıların büyük bir çoğunluğu (\%58,3) 26-37 yaş aralığında iken, sektörde çalışma sürelerinin \%46,7 oranla 6-10 yıl arasında olduğu görülmektedir. Kurumda çalışma sürelerinin ise \%62,2 lik oranla (112 kişi) 1-5 yıl arasında değiştiği görülmektedir. Söz konusu çalışanların büyük çoğunluğu (\%68,9-124 kişi) Lisansüstü eğitime sahip iken, pozisyonlarına bakıldığında \%39,4' ünün (71 kişi) personel statüsünde, \%28,9 'unun (52 kişi) alt düzey yönetici pozisyonunda çalıştığı görülmektedir. 
D. Özyılmaz Misican - N. Türkoğlu 11/1 (2019) 173-188

Tablo 1. Katılımcıların Demografik Özellikleri

\begin{tabular}{|c|c|c|c|c|c|c|}
\hline & $\bar{n}$ & $\%$ & & & $\bar{n}$ & $\%$ \\
\hline Cinsiyet(n=180) & & & Çalışma Süresi(n=180 & & & \\
\hline Erkek & 98 & 54,4 & 1 yıldan az & & 2 & 1,1 \\
\hline Kadın & 82 & 45,6 & $1-5$ yil & & 53 & 29,4 \\
\hline Medeni Durum(n=180) & & & 6-10 y1l & & 84 & 46,7 \\
\hline Evli & 48 & 26,7 & $11-15$ yıl & & 2 & 1,1 \\
\hline Bekar & 102 & 56,7 & $16-20$ y1l & & 25 & 13,9 \\
\hline Boşanmış & 30 & 16,7 & 20 yıldan fazla & & 14 & 7,8 \\
\hline Eğitim Durumu(n=180) & & & $\begin{array}{l}\text { Kurumda } \\
\text { Süresi(n=180) }\end{array}$ & Çalışma & & \\
\hline Önlisans & 4 & 2,2 & 1 yıldan az & & 38 & 21,1 \\
\hline Lisans & 52 & 28,9 & $1-5$ y1l & & 112 & 62,2 \\
\hline Lisansüstü & 124 & 68,9 & 6-10 y1l & & 23 & 12,8 \\
\hline Yaş(n=180) & & & $11-15$ yil & & 7 & 3,9 \\
\hline 25 ve altı & 34 & 18,9 & Pozisyon(n=180) & & & \\
\hline $26-37$ & 105 & 58,3 & Üst düzey yönetici & & 23 & 12,8 \\
\hline $38-57$ & 35 & 19,4 & Orta düzey yönetici & & 34 & 18,9 \\
\hline 58 ve üstü & 6 & 3,3 & Alt düzey yönetici & & 52 & 28,9 \\
\hline XXX & $X X$ & $X X$ & Personel & & 71 & 39,4 \\
\hline
\end{tabular}

4.2. Psikolojik Sermaye Ölçeği Faktör Analizi

Araştırma kapsamında kullanılan ölçeklerin geçerliliğini belirlemek için açıklayıcı faktör analizi uygulanmıştır. Faktör sayısı tespit edilirken özdeğerin 1'den büyük olmasına ve ilgili faktör ile en az 0,50 değerinde yüke sahip olmasına (Hair vd., 2010) dikkat edilmiş ve Varimax döndürme yöntemi uygulanmıştır. Katılımcılardan elde edilen verilerin açıklayıcı faktör analizine uygun olup olmadığının belirlenmesi için Kaiser-Meyer-Olkin (KMO) değeri ve Barlett testi sonucunun anlamlı çıkması önem taşımaktadır (Kaya, 2013: 180).

Tablo.2'de Psikolojik Sermaye Ölçeğine ilişkin faktör analizi sonuçları ve genel puan sonuçlarına yer verilmiştir. Psikolojik Sermaye ölçeğinin KMO değeri 0,604'dür. Faktör analizine devam edebilmek için KMO değerinin 0,50 'den yüksek olması beklenir. Söz konusu değerin yüksekliği ölçekte yer alan değişkenlerin, diğer değişkenler tarafından tahmin edilebileceğinin işaretidir (Kaya, 2013: 180). Bartlett Küresellik testi sonuçları da anlamlıdır $\left(x^{2}=1372,107 ; \mathrm{p}<0,001\right)$. Her iki testin sonucuna bakıldığında, Psikolojik Sermaye Ölçeği'ne ilişkin verilere faktör analizi yapılmasının uygun olacağı görülmüştür.

Psikolojik sermaye Ölçeği için yapılan açılayıcı faktör analizi sonucunda; ölçekte yer alan altı madde birden fazla faktöre yük verdiğinden ve yükler arasındaki fark 0,100 'den düşük olduğu için ölçekten çıkarılmıştır. Geriye kalan 18 madde beş faktör altında toplanmış ve varyansın yaklaşık \%64'ünü açıklamıştır. Ölçeğin orijinalinde dört boyut olmasına rağmen yapılan bu araştırmada maddeler beş boyut altında toplanmıştır. İlk faktör dört maddeden oluşmakta ve varyansın yaklaşık \%17'sini açıklamaktadır. Bu faktörde bir araya gelen maddeler ölçeğin orjinalinde olduğu gibi çalışanların iyimserlik yönünü ele aldığı için ilk faktör "iyimserlik" olarak adlandırılmıştır. Ölçeğin ikinci faktörü beş maddeden oluşmakta ve varyansın yaklaşık \%16'sını açıklamaktadır. Bir araya gelen maddeler ölçeğin orjinalinde olduğu gibi daha çok çalışanların umut düzeylerini belirlemeye yönelik ifadelerden oluştuğu için "umut" olarak adlandırılmıştır. Dördüncü ve beşinci faktörler de toplamda beş ifadeden oluşmakta ve varyansın yaklaşık \%18'ini açıklamaktadır. Bu ifadeler de ölçeğin orjinalinde olduğu gibi çalışanların öz yeterlilik ve psikolojik dayanıklılık düzeylerini ölçmeye yönelik ifadelerden oluşmaktadır. Ancak orjinal ölçekten farklı olarak bu çalışmada üçüncü faktör dört maddeden oluşmuş ve varyansın yaklaşık \%13'ünü açıklamıştır. Gerçekleştirilen alan yazın araştırması neticesinde söz konusu faktör altında toplanan ifadelerin daha çok çalışanların davranış biçimini harekete geçirmeye yönelik kendi yetenekleri ile ilgili güvenleri veya inançlarını kapsayan ve etkinlik olarak adlandırılan kavramı kapsadığı görülmektedir. Ayrıca alan yazında etkinlik kavramı umut kavramı ile ilişkilendirilmekte ve amaca yönelik kısayollar oluşturmak, eylemde bulunmak ve başarılı olma umuduna 


\section{D. Özyılmaz Misican - N. Türkoğlu 11/1 (2019) 173-188}

ilişkin inanç olarak tanımlanmaktadır (Erkmen ve Esen, 2012: 91). Üçüncü faktör alan yazından hareketle bu çalışmada "etkinlik" olarak adlandırılmıştır.

Tablo 2. Psikolojik Sermaye Ölçeği Faktör Analizi Sonuçları

\begin{tabular}{|c|c|c|c|c|}
\hline Psikolojik Sermaye Ölçeği & $\begin{array}{l}\text { Faktör } \\
\text { Yükü }\end{array}$ & Ortalama & $\begin{array}{l}\text { Açılanan } \\
\text { Varyans }\end{array}$ & Özdeğerler \\
\hline İyimserlik & & 3,127 & 16,751 & 3,015 \\
\hline $\begin{array}{l}\text { İşimle ilgili gelecekte basıma ne geleceği konusunda } \\
\text { iyimserimdir }\end{array}$ & ,856 & 2,761 & & \\
\hline $\begin{array}{l}\text { İşimde bir terslikle karsılaştığımda, onu atlatma } \\
\text { konusunda sıkıntı yasıorum. }\end{array}$ & ,828 & 3,272 & & \\
\hline İşimle ilgili şeylerin daima iyi tarafını görürüm. & ,770 & 2,744 & & \\
\hline $\begin{array}{l}\text { Bu iş yerinde, işler asla benim istediğim şekilde } \\
\text { yürümez. }\end{array}$ & ,673 & 3,733 & & \\
\hline Umut & & 3,755 & 16,091 & 2,896 \\
\hline $\begin{array}{l}\text { Mevcut iş amaçlarıma ulaşmak için birçok yol } \\
\text { düşünebilirim. }\end{array}$ & 841 & 3,688 & & \\
\hline $\begin{array}{l}\text { Eğer çalışırken kendimi bir tıkanıklık içinde bulursam, } \\
\text { bundan kurtulmak için birçok yol düşünebilirim. }\end{array}$ & ,719 & 3,794 & & \\
\hline Herhangi bir problemin çözümü için birçok yol vardır & 671 & 3,827 & & \\
\hline İşimde birçok şeyleri halledebileceğimi hissediyorum. & 637 & 3,538 & & \\
\hline $\begin{array}{l}\text { Daha önceleri zorluklar yasadığım için, isimdeki zor } \\
\text { zamanların üstesinden gelebilirim. }\end{array}$ & ,602 & 3,927 & & \\
\hline Etkinlik & & 3,525 & 13,116 & 2,361 \\
\hline $\begin{array}{l}\text { Eğer işimde bir şeyler benim için yanlış gidecekse, o } \\
\text { şekilde gider. (iyimserlik) }\end{array}$ & ,723 & 2,655 & & \\
\hline $\begin{array}{l}\text { Yönetimin katıldığı toplantılarda kendi çalışma alanımı } \\
\text { açıklarken kendime güvenirim. (öz yeterlilik) }\end{array}$ & ,709 & 3,905 & & \\
\hline $\begin{array}{l}\text { Eğer zorunda kalırsam, işimde kendi başıma yeterim. } \\
\text { (pd) }\end{array}$ & 686 & 3,816 & & \\
\hline $\begin{array}{l}\text { İsime "her şeyde bir hayır vardır" şeklinde yaklaşıyorum } \\
\text { (iyimserlik) }\end{array}$ & ,656 & 3,722 & & \\
\hline Öz Yeterlilik & & 3,455 & 10,442 & 1,880 \\
\hline $\begin{array}{l}\text { Bir grup iş arkadaşıma bir bilgi sunarken kendime } \\
\text { güvenirim. }\end{array}$ & ,881 & 4,033 & & \\
\hline $\begin{array}{l}\text { Çalışma alanimda, hedefler/amaçlar belirlemede } \\
\text { kendime güvenirim }\end{array}$ & ,762 & 4,066 & & \\
\hline $\begin{array}{l}\text { Genellikle, işimdeki stresli şeyleri sakin bir şekilde } \\
\text { hallederim. }\end{array}$ &, 514 & 2,266 & & \\
\hline Psikolojik Dayanıklılık & & 3,991 & 7,485 & 1,347 \\
\hline İşimdeki zorlukları genellikle bir şekilde hallederim. & ,726 & 3,988 & & \\
\hline Şu anda iş amaçlarımı sıkı bir şekilde takip ediyorum. & ,722 & 3,994 & & \\
\hline
\end{tabular}




\subsection{Duygusal Emek Ölçeği Faktör Analizi}

Psikolojik Sermaye Ölçeğinin geçerliliği belirlendikten sonra aynı varsayımlar ile Duygusal Emek Ölçeğinin geçerliliğini belirlemek amacıyla açıklayıcı faktör analizi yapılmıştır ve sonuçları Tablo 3'de sunulmuştur.

Tablo 3. Duygusal Emek Ölçeği Faktör Analizi Sonuçları

\begin{tabular}{|c|c|c|c|c|}
\hline Duygusal Emek Ölçeği & $\begin{array}{l}\text { Faktör } \\
\text { Yükü }\end{array}$ & Ortalama & $\begin{array}{l}\text { Açılkanan } \\
\text { Varyans }\end{array}$ & Özdeğerler \\
\hline Doğal Duygular & & 2,641 & 35,627 & 3,206 \\
\hline Müşterilere/ Çalışanlara gösterdiğim duygular doğaldır. & 909 & 2,038 & & \\
\hline Müşterilere/ Çalışanlara gösterdiğim duygular gerçektir. & ,903 & 2,322 & & \\
\hline $\begin{array}{l}\text { Müşterilere/ Çalışanlara karşı hislerim o an hissettiklerimle } \\
\text { aynıdır. }\end{array}$ & 895 & 2,205 & & \\
\hline $\begin{array}{l}\text { Mesleğimi yaparken hissetmediğim duyguları } \\
\text { hissediyormuşum gibi davranırım. }\end{array}$ & 661 & 4,000 & & \\
\hline Yüzeysel Rol Yapma & & 3,946 & 28,810 & 2,593 \\
\hline $\begin{array}{l}\text { Müşterilere/Çalışanlara göstermem gereken davranışları } \\
\text { hissedebilmek için kendimi zorlarım. }\end{array}$ & ,905 & 3,900 & & \\
\hline $\begin{array}{l}\text { Müşterilerle/ Çalışanlarla ilgilenirken kötü hissetsem bile } \\
\text { iyiymişim gibi davranırım. }\end{array}$ & 872 & 4,038 & & \\
\hline $\begin{array}{l}\text { Müşterilere/Çalışanlara karşı gerçekten hissettiklerimden } \\
\text { farklı davranırım. }\end{array}$ & ,823 & 3,900 & & \\
\hline Derinden Rol Yapma & & 4,077 & 14,739 & 1,326 \\
\hline $\begin{array}{l}\text { Müşterilere/ Çalışanlara göstermem gereken içimdeki } \\
\text { duyguları geliştirmek için çalışırım. }\end{array}$ & 859 & 4,016 & & \\
\hline $\begin{array}{l}\text { Müşterilerle/çalışanlarla ile ilgilenirken bir şov yapar gibi } \\
\text { ekstra performans sergilerim. }\end{array}$ & ,757 & 4,138 & & \\
\hline
\end{tabular}

Duygusal Emek Ölçeği'nin KMO değeri 0,709 olarak, Barlett testi sonucu ise $x^{2}=1132,188 ; p<0,001$ olarak hesaplanmıştır. Her iki testin sonucuna bakıldığında, duygusal Emek Ölçeği'ne ilişkin verilere faktör analizi yapılmasının uygun olacağı belirlenmiştir. Yapılan açıklayıcı faktör analizi sonucunda; ölçekte yer alan beş madde iki faktöre yük verdiğinden ve yükler arasındaki fark 0,100'den düşük olduğu için ölçekten çıkarılmıştır. Geriye kalan 9 madde 3 faktör altında toplanmış ve varyansın yaklaşık \% $78^{\prime}$ ini açıklamaktadır. Duygusal Emek Ölçeği'nin ilk faktörü dört maddeden oluşmaktadır. Bu faktör varyansın yaklaşık \%36'sını açıklamaktadır. Bu faktörde toplanan maddelerin daha çok çalışanların doğal duygu durumlarını yansıttığı görüşünden hareketle faktör "doğal duygular" olarak adlandırılmıştır. İkinci faktörde ise toplanan madde sayısı 3'tür ve varyansın yaklaşık \%29'unu açıklamaktadır. Madde ifadelerine bakıldığında ise çalışanların duygusal emek yönlerinin yüzeysel rol yapma kavramı ile özdeşleştiği görüldüğünden, söz konusu faktör "yüzeysel rol yapma" olarak kavramlaştırılmıştır. Üçüncü faktörün ise varyansın yaklaşık \%15'ini açıkladığı ve madde ifadelerinin çalışanların derinden rol yaptığına yönelik ifadeleri kapsadığı görülmüş ve faktör "derinden rol yapma" olarak adlandırılmıştır.

\subsection{Değişkenlere Ait Regresyon Analizleri}

Psikolojik sermaye boyutlarının çalışanların doğal duyguları üzerindeki etkisini açıklamak için çoklu regresyon analizi yapılmıştır. Tablo: 4' de görüldüğü gibi iyimserlik, umut, etkinlik, öz yeterlilik ve psikolojik dayanıklılık bağımsız değişkenleri, bağımlı değişken olan doğal duyguların 0,224 'ünü $(F=10,067 ; p<0,001)$ açıklamaktadır. Bu analizde $\mathrm{H} 1, \mathrm{H} 2, \mathrm{H} 3, \mathrm{H} 4$ ve $\mathrm{H} 5$ : hipotezleri test edilmiştir. Çalışanların iyimserlik 


\section{D. Özyılmaz Misican - N. Türkoğlu 11/1 (2019) 173-188}

duygularının doğal duyguları üzerinde etkisinin olmadığı $(p>, 05)$, umut düzeylerinin doğal duygularını 0,174 oranında, etkinlik düzeylerinin 0,389 oranında, öz yeterlilik düzeylerin de 0,604 oranında pozitif yönde etkilediği, ancak psikolojik dayanıklılık düzeylerinin doğal duyguları üzerinde herhangi bir etkiye sahip olmadığ1 $(p>, 05)$ görülmektedir. Bu bağlamda H2, H3 ve H4 hipotezleri desteklenirken, H1 ve H5 hipotezleri desteklenmemiştir.

Tablo 4. Psikolojik Sermaye Boyutlarının Duygusal Emeğin Doğal Duygu Boyutu Üzerindeki Etkisi

\begin{tabular}{|c|c|c|c|c|c|}
\hline \multirow[b]{2}{*}{ Değişken } & \multicolumn{2}{|c|}{$\begin{array}{c}\text { Standardize Edilmemiş } \\
\text { Katsayılar }\end{array}$} & \multicolumn{2}{|c|}{ Standart Katsayılar } & \multirow[b]{2}{*}{ Sig. } \\
\hline & $\beta$ & Std. Hata & $\beta$ & $\mathbf{t}$ & \\
\hline (Sabit) & $-3,056$ & 1,103 & & $-2,771$ & ,006 \\
\hline İyimserlik &,- 051 & 113 &,- 032 &,- 455 & 650 \\
\hline Umut & ,174 & ,087 & 155 & 2,003 & ,047 \\
\hline Etkinlik & ,389 & 143 & , 188 & 2,718 & ,007 \\
\hline Öz-yeterlilik & 604, & 142, & ,326 & 4,245 & ,000 \\
\hline Psikolojik Dayanıklılık & , 438 & ,226 & , 130 & 1,940 & 054 \\
\hline
\end{tabular}

Psikolojik sermaye boyutlarının çalışanların bağımlı değişken olan yüzeysel rol yapma üzerindeki etkisini açıklamak için çoklu regresyon analizi yapılmıştır. Tablo: 5'de görüldüğü gibi iyimserlik, umut, etkinlik, öz yeterlilik ve psikolojik dayanıklılık bağımsız değişkenleri, bağımlı değişken olan yüzeysel rol yapma durumunun 0,246'sını açıklamaktadır. Bu analizde H6, H7, H8, H9 ve H10 hipotezleri test edilmiştir. Tablodan da görüldüğü gibi çalışanların umut, etkinlik ve psikolojik dayanıklılık düzeylerinin yüzeysel rol yapma durumları üzerinde anlamlı etkiye sahip değilken ( $p>, 05)$, iyimserlik düzeyleri 0,561 düzeyinde pozitif yönde, öz yeterlilik düzeyleri $-0,570$ negatif yönde etkiye sahiptir. Bu bağlamda H7, H8, H9, H10 hipotezleri desteklenmezken, H6 hipotezinin desteklendiği görülmektedir.

Tablo 5. Psikolojik Sermaye Boyutlarının Yüzeysel Rol Yapma Boyutu Üzerindeki Etkisi

\begin{tabular}{|c|c|c|c|c|c|}
\hline \multirow[b]{2}{*}{ Değişken } & \multicolumn{2}{|c|}{$\begin{array}{c}\text { Standardize Edilmemiş } \\
\text { Katsayılar } \\
\end{array}$} & \multicolumn{2}{|c|}{ Standart Katsayılar } & \multirow[b]{2}{*}{ Sig. } \\
\hline & $\beta$ & Std. Hata & $\beta$ & $\mathbf{t}$ & \\
\hline (Sabit) & 4,045 & ,914 & & 4,424 & ,000 \\
\hline İyimserlik &, 561 & ,094 & ,410 & 5,989 & ,000 \\
\hline Umut &,- 040 & ,072 &,- 043 &,- 559 &, 577 \\
\hline Etkinlik &,- 107 & ,119 &,- 062 &,- 907 & ,366 \\
\hline Öz-yeterlilik &,- 570 & ,118 &,- 366 & $-4,828$ &, 000 \\
\hline Psikolojik Dayanıklılık & 162 & 187 & 057 & ,863 & ,389 \\
\hline
\end{tabular}

Bağımlı Değişken: Yüzeysel Rol Yapma; $R=0,496 ; R^{2}=0,246 ;$ Düzeltilmiş $R^{2}=0,224 ; F=11,344 ;$ Sig F=0,000

Tablo:6 'da ise katılımcıların iyimserlik, umut, etkinlik, öz yeterlilik ve psikolojik dayanıklılık durumlarının bağımlı değişken olan derinden rol yapma durumları üzerindeki etkisi test edilmeye çalışılmıştır. Söz konusu bağımsız değişkenler bağımlı değişken olan yüzeysel rol yapma durumunu 0,208 oranında açıklamaktadır. 
Tablo 6. Psikolojik Sermaye Boyutlarının Derinden Rol Yapma Boyutu Üzerindeki Etkisi

\begin{tabular}{|c|c|c|c|c|c|}
\hline \multirow[b]{2}{*}{ Değişken } & \multicolumn{2}{|c|}{ Standardize Edilmemiş Katsayılar } & \multicolumn{2}{|c|}{ Standart Katsayılar } & \multirow[b]{2}{*}{ Sig. } \\
\hline & $\beta$ & Std. Hata & $\beta$ & $\mathbf{t}$ & \\
\hline (Sabit) & 1,620 & ,681 & & 2,379 & 018 \\
\hline İyimserlik &,- 306 & 070 &,- 308 & $-4,385$ & ,000 \\
\hline Umut & ,034 &, 054 & 049 & ,629 &, 530 \\
\hline Etkinlik & , 030 & 088 & ,024 & 345 & ,730 \\
\hline Öz-yeterlilik & ,116 & ,088 & 102 & 1,317 & , 190 \\
\hline Psikolojik Dayanıklılık & 696 & 140 & ,338 & 4,992 & ,000 \\
\hline
\end{tabular}

Gerçekleştirilen regresyon analizi ile H11, H12, H13, H14 ve H15 hipotezleri test edilmiştir. Analiz sonucunda çalışanların iyimserlik durumlarının derinden rol yapma durumları üzerinde $-0,306$ oranında negatif etkiye sahip olduğu, psikolojik dayanıklılık durumlarının da derinden rol yapma durumları üzerinde 0,696 oranında pozitif etkiye sahip olduğu tespit edilmiştir. Çalışanların umut, etkinlik ve öz yeterlilik düzeylerinin ise derinden rol yapma durumları üzerinde herhangi bir etkiye sahip olmadığı ( $p>05$ ) bulgulanmıştır. Bu durumda H12, H13, H14 ve H15 hipotezleri reddedilirken, H11 hipotezinin desteklendiği görülmektedir.

Psikolojik sermayenin duygusal emeğin alt boyutlarına yönelik hipotez sonuçlarına bakıldığında; iyimserlik boyutunun doğal duygu gösterimleri üzerinde anlamlı bir etkisi olmadığı görülmektedir. İyimser olan çalışanların yüzeysel rol yapma davranışları yüksekken, derinden rol yapma davranışları düşüktür. Umutlu ve etkin olan çalışanların doğal duygu davranışlarını gösterme yetisi varken; umut ve etkinlik boyutlarının yüzeysel rol yapma ve derinden rol yapma üzerinde anlamlı bir etkisi yoktur. Psikolojik dayanıklılığın ise doğal duygular ve yüzeysel rol yapma davranışı üzerinde anlamlı bir etkisi olmadığı tespit edilirken; psikolojik dayanıklılığı yüksek olan çalışanların derinden rol yapma davranışları yüksektir. Özyeterlilik boyutu, doğal duygu davranışlarını pozitif yönde etkilerken; yüzeysel rol yapma davranışını negatif yönde etkilemektedir. Derinden rol yapma davranışı üzerinde ise anlamlı bir etki tespit edilmemiştir.

\section{Sonuç}

Bu çalışma psikolojik sermayenin duygusal emek üzerindeki etkisine unsurlar bazında vurgu yapmaktadır. Literatürde psikolojik sermaye ve duygusal emeği konu alan çalışmalar nispeden yeni çalışılmaya başlasada çalışmaların ortak sonuçları psikolojik sermaye ve duygusal emek arasında istatistiksel olarak anlamlı bir ilişki olduğu yönündedir. Bu çalışmalarda psikolojik sermayenin duygusal emeğin yüzeysel ve derinden rol yapma boyutunu negatif yönde, doğal duygu gösterimlerini ise pozitif yönde etkilediği görülmektedir (Begenirbaş, 2015; Tokmak, 2014). Bu çalışmada ise daha farklı tespitler oraya çıkmıştır. Psikolojik sermayenin umut, etkinlik ve öz yeterlilik boyutu doğal duygu gösterimlerini pozitif yönde etkilerken; iyimserlik ve psikolojik dayanıklılık boyutu ile aralarında anlamlı bir ilişki tespit edilememiştir. Yüzeysel rol yapma davranışı, öz yeterlilik boyutu ile negatif yönde; iyimserlik boyutu ile pozitif yönde etkileşim halindeyken; umut, etkinlik ve psikolojik dayanıklılık boyutları ile anlamlı bir ilişki saptanamamıştır. İyimserlik boyutu derinden rol yapma davranışı ile negatif yönde, psikolojik dayanıklılık boyutu ile pozitif yönde etkileşim halindedir. Umut, etkinlik ve öz yeterlilik ile anlamlı bir etki tespit edilememiştir.

Bu bulgular neticesinde kurumsal satış ekibinde yer alan çalışanların umut, etkinlik ve öz yeterlilik yetileri yüksek oldukça bu çalışanların yaptıkları işlerinde kendi duygularını işe adapte edebilmelerini kolaylaştıracaktır. İşlerinde doğal duygu gösterimleri artmaya başlayacaktır. Psikolojik sermayesi daha yüksek olan çalışanların iş performanslarını gösterirken firmanın kâr ve verimlilik temelinde şekillendirdiği beklenilen davranışa karşı daha doğal duygu gösterimlerinde bulunduğu gözlemlenmektedir. Psikolojik sermayesi düşük olan çalışanların ise doğal duygu gösterimleri düşük olmasına rağmen yine de beklenilen davranışı sergilemek adına sahte tavırlar sergileyerek yüzeysel rol yapma davranışına yönlendikleri görülmektedir. Özellikle iyimser olan çalışanların iş performanslarında kişiliklerinden farklı durumlarla 
karşılaştıklarında olayı içselleştirmeden kendilerini duruma adapte ederek yüzeysel rol yapma tavrına kaymaktadırlar. Ancak, çalışmada çalışanların duygusal emek yönünün oldukça güçlü çıkması duygusal emeği ve bu kavramı etkileyen faktörleri daha karmaşık hale getirmektedir. Çünkü psikolojik sermayenin doğal duyguları pozitif yönde, yüzeysel rol yapma ve derinden rol yapma davranışını negatif yönde etkileyen keskin tavrı bu çalışmada gözlemlenememiştir. Kavram, psikolojik sermayeden daha bağımsız bir noktaya taşınmaktadır. Artan işsizlik rakamları, iş güvencesi yerine istihdam edilebilirlik kaygısı çalışanları mecburen kendilerinden taviz verdikleri bir noktaya kaydırmaktadır. Kendi duygularına yabancılaşarak, yüzeysel rol yapma davranış kalıplarına girmeleri çalışanları kendi kişiliklerinde de uzaklaştırmaktadır. Çalışma hayatının beklenilen davranışı, çalışan tarafından zorunlu, istenilen bir davranışa dönüştürülmek zorunda bırakılmaktadır. Bu durum, muhakkak ki çalışan üzerinde baskı ve strese yol açsa da istihdam yarışından geri kalmamak adına çalışan hissetmediği duyguları takınmak zorunda bırakılmaktadır. Çalışmada da çalışanlar duygusal emeğin en çok derinden rol yapma tavrını göstermektedir. (Derinden rol yapma davranışı ortalaması 4,077; yüzeysel rol yapma davranışı ortalaması 3,946; doğal duygular gösterme davranışı ortalaması 2,641.) Çalışanların iş süreçlerinde duygularını kontrol ederek hissetmesi gereken duyguların rol kalıplarına girmeleri çalışma hayatının girdabını daha da büyütmektedir. Doğal duygu gösterimleri davranışının çalışmada da daha az düzeyde sergilenmesi çalışma hayatının geldiği noktayı eleştiren düşünceleri haklılaştırmaktadır.

Duygular bireyi harekete geçirmek ve gelecek davranışları şekillendirme de en önemli fonksiyonlar olarak görülse de günümüz çalışma hayatında duygular profesyonelleşmekte, çalışma kavramı çalışanın bütün bedenini ele geçirmektedir. Gelinen süreci Bauman (2005: 59) post modernliğin hastalığı olarak tanımlaması sürecin karşı konulamaz hoyratlığını göstermektedir. Günümüz çalışma hayatının olmazsa olmaz handikaplarından biri daha doğmaktadır. Çalışan çalışma kavramının istediği profesyonel duruşu sergiledikçe çalışma hayatında yerini alabilecek aksi takdirde yavaş yavaş istihdam edilebilirliğini kaybedecektir.

Çalışma hayatının aldığı yeni biçimler, çalışanların hem diğer çalışanlarla hem de kendileri ile olan rekabet boyutlarını derinleştirmektedir. İş güvencesi kaygısı hisseden çalışanlar kişilik tavizleri vererek performansları üzerinde bir çalışma davranışı ortaya koymaktadır. En dikkat çekici yön belirsizleşen çalışma ortamında çalışanların işsizlik ve rekabet karşısında kendi performanslarını artırmak zorunda kalmalardır. Ayrıca son yapılan çalışmalarda (Aracı, 2011; Misican ve Bedir, 2017b) çalışma hayatındaki kuşak sınıflandırmalarının silikleşmeye başlaması, kuşakların dönüşerek R kuşağı (recession kuşak) kişilik alt yapısında buluşması duygusal emeği psikolojik sermayeden daha bağımsız hale getiren yapıyı desteklemektedir. Psikolojik sermayesi düşük olan çalışanlar bile artık istihdam edilebilir olmak adına duygusal emek yönlerini güçlendirmek zorunda kalmaktadır.

Sürecin diğer tarafında yer alan firmalarında kendilerini bu kavramlara adapte etmeleri gerekmektedir. Psikolojik sermayenin ve duygusal emeğin ön plana çıktığı çalışma hayatında firmaların çalışanlarının psikolojik sermayelerini artırmalarına ve çalışanlarının doğal duygu gösterimlerini daha fazla sergileyebilecekleri duygu kalıplarına girebilmelerini sağlayacak motivasyon unsurlarını oluşturabilmeleri gerekmektedir. Böylece çalışanlar yaptıkları işe kendilerini daha ait hissederek olumlu duygular geliştirip iş performanslarını daha da artırabileceklerdir. İnsan kaynakları yönetimi kendi iş süreçlerini bu doğrultuda daha etkin hale getirmelidir. Özellikle işe alma ve yerleştirme süreçlerinde psikolojik sermayesi daha güçlü çalışanları seçebilecekleri ve kişilik yapılarına göre çalışanları daha uygun pozisyonlara yerleştirmelerini sağlayacak operasyonlar yürütmeleri firmalara büyük kazanımlar sağlayacaktır. Bu doğrultuda gerek firmaların bu farkındalıkla sürece yaklaşmaları, gerekse çalışanların iş güvencesinin kaybolduğu çalışma hayatında artan işsizlik ve rekabet karşısında kendilerini bu değişim rüzgârına adapte etme çabalarıyla çalışma hayatı daha büyük kâr ve verimlilik ekseninde büyümeye başlayacaktır. Çalışma hayatının her iki tarafının da kendilerini sürece adapte etmeleri kazan-kazan yaklaşımına göre daha etkin, daha verimli, daha iş aidiyeti yüksek bir çalışma ortamı yaratacaktır.

Bu çalı̧̧ma ile bundan sonra yapılacak çalışmalara zemin hazırlanarak, psikolojik sermaye ve duygusal emeği farklı öncül ve ardıl değişkenlerle ele alınarak zenginleştirilebilir. Araştırmanın sınırlılığı çalışmanın sadece tek bir işletmede yapılmış olmasıdır. Özellikle farklı meslek gruplarında ve farklı sektörlerde ele alınarak kavramlar daha geniş perspektiflerde sorgulanabilir. Çalışma hayatının değişimlerle geldiği noktayı sorgulayabilmek ve çalışma hayatının sonu nereye gidiyor sorusunun cevabını almak adına çalışmaların daha genellenebilir sonuçlarına ihtiyaç duyulmaktadır. 


\section{KAYNAKÇA}

Aracı, M. (2011). Ekonomik krizin yarattığı R kuşağı ve çalışma hayatına etkileri, Organizasyon ve Yönetim Bilimleri Dergisi, 3 (2), 1ssn: 1309 -8039, 211-220.

Avey, J. B., Wernsing, T. S. and Luthans, F. (2008). Can positive employees help positive organizational change? impact of psychological capital and emotions on relevant attitudes and behaviors, Journal of Applied Behavioral Science, 44(1), 48-70.

Ashforth, B. E. ve Humphrey, R. H. (1993). Emotional labor in service roles: the influence of identity, Academy of Management Review, 18(1): 88-115.

Bandura, A. (1982). Self-efficacy mechanism in human agency, American Psychologist, 37(2), 122-147.

Basım, H.N., Begenirbaş M. (2012). Çalışma yaşamında duygusal emek: bir ölçek uyarlama çalışması, Celal Bayar Üniversitesi İktisadi ve İdari Bilimler Fakültesi Yönetim ve Ekonomi Dergisi, 19 (1): 77-90.

Bauman, Z. (2005). Bireyselleşmiş Toplum (Çev. Yavuz Alogan), İstanbul: Ayrıntı Yayınları.

Begenirbaş, M. (2015). Psikolojik sermayenin çalışanların duygu gösterimleri ve yabancılaşmalarına etkileri: sağlık sektöründe bir araştırma, Süleyman Demirel Üniversitesi İ̈BF Dergisi, 20(3): 249-263.

Bora, A., Bora, T., Erdoğan N. ve Üstün, İ. (2012). Boşuna mı Okuduk (3. Baskı), İletişim Yayınları, İstanbul.

Brandt, T., Gomes, J. F. S. ve Boyanova, D. (2011). Personality and psychological capital as indicators of future job success?, LTA, 3/11, 263-289.

Brotheridge, C., Lee R.T. (2003). Development and validation of the emotional labour scale, Journal of Occupational and Organizational Psychology, 76(3): 365-379.

Brotheridge, C. M., Grandey A. A. (2002). Emotional labor and burnout: comparing two perspectives of people work, Journal of Vocational Behavior, 60(1): 17-39.

Chau, S.L., Dahling, J. J., Levy, P. E., Diefendorff, J. M. (2009). A predictive study of emotional labor and turnover, Journal of Organizational Behavior, 30(8): 1151-1163.

Chu, K.H.L., Murrmann, S.K. (2006). Development and validation of the hospitality emotional labor scale, Tourism Management, 27(6), 1181-1191.

Çelik, D.A., Öz, E.Ü. (2011). The effects of emotional dissonance and quality of work life perceptions on absenteeism and turnover intentions among turkish call center employees, Procedia-Social and Behavioral Sciences, 30, 2515-2519.

Çetin, F., Şeşen, H. ve Basım H. N. (2013). Örgütsel psikolojik sermayenin tükenmişlik sürecine etkileri: kamu sektöründe bir araştırma, Anadolu Üniversitesi Sosyal Bilimler Dergisi, 13(3), 95-108.

Çetin, F., Basım, H. (2012). Örgütsel psikolojik sermaye: bir ölçek uyarlama çalışması, Amme İdare Dergisi, $45(1), 121-137$.

Diefendorff, J. M., Meredith H. Croyle ve Gosserand R. H. (2005). The dimensionality and antecedents of emotional labor strategies, Journal of Vocational Behavior, 66(2): 339-357.

Diefendorff, J. M., Gosserand, R.H. (2003). Understanding the emotional labor process: a control theory perspective, Journal of Organizational Behavior, 24(8), 2003, 945-953.

Duffy, J. R. (2013). Quality Caring: In Nursing and Health Systems, 2nd Edition, Springer Publishing Company, New York.

Erkmen, T. ve Esen, E. (2012). Psikolojik sermaye konusunda 2003-2011 yıllarında yapılan çalışmaların kategorik olarak incelenmesi, Mustafa Kemal Üniversitesi Sosyal Bilimler Enstitüsü Dergisi, 9 (19), s. 89-103.

Fredrikson, B.L., Losada, M.F. (2005). Positive affect and the complex dynamics of human flourishing, American Psychologist, 60(7): 678-686. 
D. Özyılmaz Misican - N. Türkoğlu 11/1 (2019) 173-188

Fredrickson, B.L. (2001). The role of positive emotions in positive psychology: the broaden and build theory of positive emotions, American Psychologist, 56: 218-226.

Froymovich, R. (2013). End Of The Good Life: How The Financial Crisis Threatens A Lost Generation-And What We Can Do About It, Newyork: Harper Perennial.

Geçtan, E. (2003). Psikodinamik Psikiyatri ve Normaldışı Davranışlar, Metis Yayınları, İstanbul.

Gorz, A. (2001). Yaşadığımız Sefalet (Çev: N. Tutal), Ayrıntı Yayınları, İstanbul.

Grandey, A. A. (2000). Emotional regulation in the workplace: a new way to conceptualize emotional labor, Journal of Occupational Health Psychology, 5(1): 95.

Hair, J.F. Jr., Black, W.C., Babin, B.J. ve Anderson, R.E. (2010). Multivariate Data Analysis. Prentice Hall, NJ.

Harms, P. D. ve Luthans, F. (2012). Measuring implicit psychological constructs in organizational behavior: an example using psychological capital, Journal of Organizational Behavior, 33(4), 589-594.

Hebb, Donald O. (1958). The motivating effects of exteroceptive stimulation, American Psychologist, 13(3): 109-113.

Hochschild, A., R. (1983). The Managed Heart: The Commercialization of Human Feeling. University of California Press, California.

Judge, T.A., Woolf, E.F. Hurst, C. (2009). Is emotional labor more difficult for some than for others? A multilevel, experience-sampling study, Personnel Psychology, 62,57-88.

Kara, A., Begenirbaş, M. (2016). Çalışanların psikolojik sermaye algıları onların duygusal rol davranışlarını etkiler mi? turizm sektöründe bir araştırma, EUL Journal of Social Sciences VII(I):50-66.

Kart, E. (2010). Nitelikli İşgücünün Küresel Trajedisi, Kavim Kitap, İstanbul.

Kaya, U., Özhan, Ç.K. (2012). Duygusal emek ve tükenmişlik ilişkisi: turist rehberleri üzerine bir araştırma, Çalışma İlişkileri Dergisi, 3(2): 109-130.

Kaya, M. F. (2013). Sürdürülebilir kalkınmaya yönelik tutum ölçeği geliştirme çalışması, Marmara Coğrafya Dergisi (28), s. 175-193.

Kleinman, S., Copp, M.A. (1993). Emotions and Fieldwork, Sage Publications, Newbury Park.

Kruml, S. M., Geddes, D. (2000). Exploring The Dimensions of Emotional Labor: The Heart of Hochschild's Work, Management Communication Quarterly, 14/8, 8-49.

Lam, W., Chen, Z. (2012). When I put on my service mask: determinants and outcomes of emotional labor among hotel service providers according to affective event theory, International Journal of Hospitality Management, 31, 3-11.

Lupton, D. (2002). Duygusal Yaşantı. (Mustafa Cemal, Çev.), Ayrıntı Yayınları, İstanbul.

Luthans, F., Avey, J. , Avolio, B. J. ve Peterson, S. (2010). The development and resulting performance impact of positive psychological capital, Human Resource Development Quarterly , 21 (1), 41-67.

Luthans, F., ve Youssef, C. M. (2007). Emerging positive organizational behavior, Journal of Management, 33, 321-349.

Luthans, F., Youssef, C. M. ve Avolio, B. J. (2007). Psychological Capital: Developing the Human Competitive Edge, 1st Edition, Oxford University Press, New York.

Luthans, F. ve Jensen S. M. (2002). Hope: A new positive strength for human resource development, Human Resource Development Review, 1 (3): 304-322.

Luthans, F., Luthans, K. W. ve Luthans, B. C. (2004). Positive psychological capital: beyond human and social capital, Business Horizons, 47(1), 45-50.

Mann, S. (2007). Expectations of emotional display in the workplace, Leadership \& Organizational development Journal. 28 (6), 552-570. 
Man, F., Öz, C.S. (2009). Göründüğü gibi olamamak ya da olduğu gibi görünememek: Çağrı merkezlerinde duygusal emek, Çalışma ve Toplum Dergisi, 1, 75-184.

Misican, D. ve Bedir, E. (2017). Çalışma hayatında yaşanan değişimin ortaya çıardığı R kuşağının psikolojik sözleşme algısı, Gazi Üniversitesi İ̈BF Dergisi, 19/1, 242-273.

Misican, D. ve Bedir, E. (2017b). Değişimin ortaya çıkardığı yeni kuşağın değişen kariyer algısı: bilişim sektörü uygulaması, Çalışma İlişkileri Dergisi, Cilt 8, Sayı 1, Sayfa: 118-137.

Norman, S. M., Avey, J., Nimnicht, J. L. ve Pigeon, N. G. (2010). The interactive effects of psychological capital and organizational identity on employee organizational citizenship and deviance behaviors, Journal of Leadership and Organizational Studies, 17(4), 380-391.

Onay, M. (2011). Çalışanın sahip olduğu duygusal zekâsının ve duygusal emeğinin, görev performansı ve bağlamsal performans üzerindeki etkisi, Ege Akademik Bakış, 11(4), 587-600.

Peterson, S. J., Luthans F., Avolio, B. J., Walumbwa, F. O. ve Zhangi Z. (2011). Psychological capital and employee performance: a latent growth modeling approach, Personnel Psychology. 64: 427-450.

Pugliesi, K. (1999). The consequences of emotional labor: effects on work stress, job satisfaction, and wellbeing, Motivation and Emotion, 23(2), 125-154.

Rifkin, J. (1995), The end of work.

https://www.researchgate.net/publication/39081425 RIFKIN Jeremy The end of work THe decline of the global labor force and the dawn of the post-market era (Erişim Tarihi: 10 Temmuz 2018).

Scott, B.A., Barnes, C.M. (2011). A multilevel field investigation of emotional labor, affect, work withdrawal, and gender, Academy of Management Journal, 54(1), 116-136.

Seligman, M. E. P. (2006). Learned Optimism: How to Change Your Mind and Your Life, 3rd Edition, Vintage Books, New York.

Seligman, M. E. P. (2002). Positive Psychological, Positive Prevention, and Positive Therapy. In Snyder, C. R. and Lopez, S. J. (Eds.), Handbook of Positive Psychology (p. 257-276), Oxford University Press, New York.

Seligman, M. (1998). Learned Optimism: How to Change Your Mind and Your Life, New York: Pocket Books.

Sennett, R. (2012). Karakter Aşınması-Yeni Kapitalizmde İşin Kişilik Üzerindeki Etkileri, Ayrıntı Yayınları, İstanbul.

Tuna, Y. (2008). Örgütsel iletişim sürecinde yöneticilerin duygusal zekâ yeterlilikleri, yayınlanmamış doktora tezi, Anadolu Üniversitesi Sosyal Bilimler Enstitüsü, Eskişehir.

Tokmak, İ. (2014). Duygusal emek ile işe yabancılaşma ilişkisinde psikolojik sermayenin düzenleyici etkisi, İşletme Araştırmaları Dergisi, 6/3, 134-156

Ural, A. ve Kılıç, İ. (2013). Bilimsel Araştırma Süreci ve SPSS ile Veri Analizi, Detay Yayıncılık, Ankara.

Weiss, H.M., ve Cropanzano, R. (1996). Affective events theory: a theoretical discussion of the structure, causes and consequences of affective experiences at work, Research in Organizational Behavior, 18(1): $1-79$.

Yang, F., Chang, C. (2008). Emotional labour, job satisfaction and organizational commitment amongst clinical nurses: A questionnaire survey, International Journal of Nursing Studies, 45, 879-887. 